\title{
APLIKASI PENDEKATAN THEORY OF REASONED ACTION UNTUK MEMPERIKSI MINAT MASUK MENJADI PESERTA MANDIRI BADAN PENYELENGGARA JAMINAN SOSIAL KESEHATAN (Studi Kasus: Masyarakat Kecamatan Medan Selayang)
}

\author{
Nawary Saragih \\ Universitas Katolik Santo Thomas Medan Jl. Setia Budi No. 479F, 20132, Indonesia \\ e-mail: nawary_sargih@yahoo.com.id
}

\begin{abstract}
In BPJS Health still happened paradox rights, that is for health protection there is still ambiguity happened at Mitra Hospital which not as expected with that felt by patient, for example for certain sick like cancer for chemo process only long and difficult service for certain reasons as well. This is contrary to expectations by the Minister of Health proposed by Nafsiah Mboi that BPJS Health will endeavor to bear all kinds of diseases. Based on this, the research problem is formulated "Whether the theory of reasoned action can be used to predict the interest of the community to be a Mandiri BPJS Health participant in Medan Selayang Society". The purpose of this study is to determine the application of the theory of reasoned action in predicting the interest of entering into a participant Mandiri BPJS Health. While the benefit of the research is to provide information to the management of BPJS Health about the theory of reasoned action to predict the interest to be a participant Mandiri BPJS Health. Determination of the sample is done incidentally ie kusioner given to the Society which when met with researchers in the research location. The number of samples is determined based on the maximum error (sampling error). From the research results can be concluded that: (a). Attitudes and preference groups to be participants of Independent BPJS Health on average respondents give a positive effect (strong) on the intention to behave. (b). Based on the equation of intention to enter the participants into the Mandiri BPJS Health as a requirement of 0.62 (62\%). While the effect on subjective Norm (SN) is $0.38(38 \%)$. As a consideration (a). BPJS Health Management needs to improve the consistency of services for the required attribute benefits in accordance with the demands of positive participants on the presence of BPJS Health, (b). BPJS Health Management continuously needs to learn the attitudes of participants, because this can be used as a basis to increase the number of participants and improve the satisfaction of a prosperous Society.
\end{abstract}

Keywords: Theory of reasoned action, interest, Mandiri BPJS Health participants

\section{PENDAHULUAN}

Badan Penyelenggara Jaminan Sosial (BPJS) Kesehatan merupakan Badan Usaha Milik Negara yang ditugaskan khusus oleh pemerintah untuk menyelenggarakan jaminan pemeliharaan kesehatan bagi seluruh rakyat Indonesia, yaitu: Pegawai Negeri Sipil, Penerima Pensiun PNS dan TNI/POLRI, Veteran, Perintis Kemerdekaan beserta keluarganya dan Badan Usaha lainnya ataupun rakyat biasa. Untuk BPJS Kesehatan mulai beroperasi sejak tanggal 1 Januari 2014 (http://id.wikipedia.org/wiki/BPJS_Kesehatan)

Badan Pelaksana Jaminan Sosial Kesehatan bukan program melainkan sebuah badan hukum publik yang dibentuk berdasarkan UU No. 24 tahun 2011 tentang BPJS untuk menyelenggarakan 5 program Jaminan Sosial. Salah satu program Jaminan Sosial adalah Jaminan Kesehatan yang ditetapkan dengan Peraturan Presiden No. 12 tahun 2013 dan perubahannya dengan Peraturan Presiden No. 111 tahun 2013.

Bagi peserta baru BPJS Kesehatan berdasarkan ketentuan yang ada yang bersangkutan dapat mendatangi kantor BPJS Kesehatan dengan membawa : a). Foto copy KTP. b). Foto copy KK. c). Foto berwarna ukuran $3 \times 4 \mathrm{~cm}=2$ buah. Sedangkan besaran iuran bagi Pekerja Bukan Penerima Upah dan Bukan Pekerja atau sektor informal, besaran iuran premi ditanggung oleh 
pekerja sendiri yang dibayar setiap bulan per orang per bulan terdiri dari : Kelas $3=$ Rp25.500, Kelas $2=\operatorname{Rp} 42.500$, Kelas $1=\operatorname{Rp} 59.500$ per jiwa, dengan pembayaran melalui kantor Bank terdekat yang bekerjasama dengan BPJS Kesehatan (Bank Mandiri, Bank BRI dan Bank BNI).

Minat masyarakat atau warga Sumatera Utara menjadi peserta mandiri BPJS Kesehatan cukup tinggi, dan menduduki peringkat kedua secara nasional dan sudah ada sebanyak 44.441 peserta mandiri yang tercatat masuk BPJS di Sumatera Utara, sedangkan kepesertaan pertama adalah Jakarta (Kepala Pemasaran dan Kepersertaan BPJS Kesehatan Divre I, Rita Masyita Ridwan). Tingginya minat atau animo masyarakat bergabung dalam BPJS Kesehatan menunjukkan semakin pedulinya warga akan kesehatan di tengah mahalnya biaya pengobatan. Rita berharap dengan adanya program jaminan kesehatan ini agar kesejahteraan masyarakat Indonesia dapat semakin meningkat (http://www.bpjs.info/ ketenagakerjaan/ Peserta_BPJS_Kesehatan).

Rita (2013) menjelaskan, di luar peserta mandiri untuk Sumatera Utara sudah ada 4.192.297 orang yang masuk dalam BPJS Kesehatan di mana iurannya menjadi tanggungan Pemerintah, atau disebut sebagaiJD kelompok Penerima Bantuan Iuran (http://jkn.depkes.go.id.).

Dari data deskripsi di atas, menunjukkan bahwa telah terjadi peningkatan jumlah masyarakat masuk ansuransi BPJS Kesehatan. Hal ini menunjukkan bahwa telah ada peluang masyarakat kelas menengah dan bawah menjadi peserta ansuransi untuk yang diminati oleh Masyarakat Medan. Hal ini menunjukkan semakin pedulinya warga akan kesehatan di tengah mahalnya biaya pengobatan. Berdasarkan uraian ini, peneliti tertarik melakukan penelitian dengan judul: "Analisis Pendekatan Theory Of Reasoned Action Untuk Memprediksi Minat Menjadi peserta Mandiri BPJS Kesehatan pada Masyarakat di Kecamatan Medan Selayang.

\section{TINJAUAN PUSTAKA}

\section{A. Pengertian Asuransi}

Asuransi adalah istilah yang digunakan untuk merujuk pada tindakan, sistem, atau bisnis di mana perlindungan finansial (atau ganti rugi secara finansial) untuk jiwa, properti, kesehatan dan lain sebagainya mendapatkan penggantian dari kejadian-kejadian yang tidak dapat diduga yang dapat terjadi seperti kematian, kehilangan, kerusakan atau sakit, di mana melibatkan pembayaran premi secara teratur dalam jangka waktu tertentu sebagai ganti polis yang menjamin perlindungan tersebut. Istilah "diasuransikan" biasanya merujuk pada segala sesuatu yang mendapatkan perlindungan (http://id.wikipedia.org/ wiki/Asuransi).

Asuransi yang diselenggarakan oleh BPJS Kesehatan adalah untuk memberikan pelayanan kesehatan dalam berbagai aspek yang dijamin (http:// humasrspakuwon.wordpress.com/ 2013/08/16/bpjs-kesehatan-2) meliputi:

1. Pelayanan kesehatan tingkat pertama, yaitu pelayanan kesehatan non pesialistik mencakup:

a. Administrasi pelayanan

b. Pelayanan promotif dan preventif

c. Pemeriksaan, pengobatan, dan konsultasi medis

d. Tindakan medis non spesialistik, baik operatif maupun non operatif

e. Pelayanan obat dan bahan medis habis pakai

f. Transfusi darah sesuai dengan kebutuhan medis

g. Pemeriksaan penunjang diagnostik laboratorium tingkat pertama

h. Rawat inap tingkat pertama sesuai dengan indikasi.

2. Pelayanan kesehatan rujukan tingkat lanjutan, yaitu pelayanan kesehatan mencakup: a.

Rawat jalan yang meliputi:

1) Administrasi pelayanan 
2) Pemeriksaan, pengobatan dan konsultasi spesialistik oleh dokter spesialis dan subspesialis

3) Tindakan medis spesialistik sesuai dengan indikasi medis

4) Pelayanan obat dan bahan medis habis pakai

5) Pelayanan alat kesehatan implant

6) Pelayanan penunjang diagnostik lanjutan sesuai dengan indikasi medis

7) Rehabilitasi medis

8) Pelayanan darah

9) Pelayanan kedokteran forensic

10) Pelayanan jenazah di fasilitas kesehatan.

b. $\quad$ Rawat inap yang meliputi:

1). Perawatan inap non intensif

2). Perawatan inap di ruang intensif.

3). Pelayanan kesehatan lain ditetapkan oleh Menteri.

\section{B. Pengertian Pemasaran}

Perusahaan yang memproduksi akan memasarkan produk atau jasa untuk memenuhi kebutuhan konsumen. Alat yang digunakan oleh perusahaan untuk mengkomunikasikan produk yang dihasilkan kepada para konsumennya adalah dengan melakukan kegiatan pemasaran secara efektif dan efisien.

Menurut Kotler dan Amstrong (2001:7), "pemasaran adalah suatu proses sosial dan manajerial yang membuat individu dan kelompok memperoleh apa yang mereka butuhkan dan inginkan lewat penciptaan dan pertukaran timbal balik dengan produk dan nilai dengan orang lain". Sedangkan Lamb, dkk., (2001:179) menyatakan pemasaran adalah "suatu proses perencanaan dan menjalankan konsep, harga, promosi dan saluran distribusi sejumlah ide, barang dan jasa untuk menciptakan pertukaran yang mampu memuaskan tujuan individu dan organisasi".

Berdasarkan pengertian di atas, dapat dinyatakan bahwa pemasaran sebagai kegiatan manusia yang diarahkan untuk memenuhi dan memuaskan kebutuhan dan keinginan konsumen. Kegiatan pemasaran sebenarnya berkembang sejak adanya kebutuhan manusia dan usaha untuk memenuhi kebutuhan manusia menimbulkan perkembangan penggunaan alat pertukaran. Dengan adanya perkembangan tersebut mulailah dikenal transaksi jual beli. Pada masa itu, pemasaran merupakan kegiatan transaksi jual beli dimana seluruh barangbarang yang dihasilkan atau diproduksikan dengan mudah dapat dijual.

\section{Pengertian Perilaku Konsumen}

Salah satu tugas penting yang harus dilakukan oleh manajemen pemasaran adalah memahami perilaku konsumen. Akan tetapi perilaku konsumen tidak dapat secara langsung dikendalikan oleh perusahaan. Oleh karena itu informasi mengenai perilaku konsumen perlu dikumpulkan sebanyak mungkin. Perilaku konsumen merupakan tindakan langsung dalam mendapat, mengkonsumsi serta menghasilkan produk dan jasa, termasuk proses keputusan yang mendahului dan mengikuti tindakan tersebut.

Menurut Sutisna (2001:36) menyatakan bahwa perilaku konsumen adalah "perilaku pembelian yang berulang yang tanpa disertai dengan mencari informasi yang lebih banyak dan tanpa mengevaluasi pilihan dari alternative yang tersedia". Sedangkan Rangkuti (2003:58), menyatakan "perilaku konsumen (consumer behavior) adalah tindakan yang langsung terlibat dalam mendapatkan, mengkonsumsi dan menghabiskan produk dan jasa termasuk proses keputusan yang mendahului dan menyusul tindakan".

Dari definisi di atas ada tiga hal penting yang perlu digaris bawahi yaitu: 


\section{Volume 17 Nomor 2}

a. Perilaku konsumen adalah tindakan yang dilakukan oleh individu untuk memenuhi kebutuhan dan keinginannya.

b. Perilaku konsumen merupakan tindakan atau aktivitas yang dilakukan oleh individu secara fisik dalam pencarian, pengevaluasian, pemilihan, penggunaan dan pengaturan barang dan jasa.

c. Perilaku konsumen merupakan proses mental dan emosional dalam pengambilan keputusan.

Berdasarkan ketiga hal di atas, terkandung makna bahwa perilaku konsumen itu sifatnya kompleks. Hal ini disebabkan karena setiap konsumen mempunyai kebutuhan dan keinginan yang berbeda-beda, selalu berubah-ubah sehingga dapat disimpulkan bahwa perilaku konsumen secara umum adalah tindakan yang dilakukan individu, kelompok atau organisasi yang berhubungan dengan proses mental dan emosional dalam pengambilan keputusan untuk mendapatkan, menggunakan barang-barang atau jasa yang dapat memuaskan keinginan dan kebutuhannya.

Bagian pemasaran dalam meneliti perilaku konsumen perlu menemukan jenis kebutuhan atau masalah apa yang akan muncul, apa yang memunculkan mereka dan bagaimana kebutuhan atau masalah tersebut mengarahkan konsumen pada produk tertentu. Dengan mengumpulkan informasi semacam itu, bagian pemasaran dapat mengidentifikasi faktor-faktor yang paling sering memicu minat pada suatu produk dan dapat mengembangkan program pemasaran yang melibatkan faktor-faktor ini.

\section{Faktor-faktor yang Mempengaruhi Perilaku Konsumen}

Secara sistematika proses keputusan konsumen merupakan ungkapan dari kompleksitas faktor-faktor yang mempengaruhi dan membentuk proses keputusan konsumen untuk membeli. Menurut Kotler (2000:161) menggambarkan model perilaku konsumen seperti Gambar berikut:

\begin{tabular}{|c|c|}
\hline $\begin{array}{c}\text { Marketing } \\
\text { Stimuli }\end{array}$ & $\begin{array}{l}\text { Other } \\
\text { Stimuli }\end{array}$ \\
\hline $\begin{array}{l}\text { Product } \\
\text { Price } \\
\text { Place } \\
\text { Promotion }\end{array}$ & $\begin{array}{l}\text { Economic } \\
\text { Technologies } \\
\text { Political } \\
\text { Cultural }\end{array}$ \\
\hline
\end{tabular}

\begin{tabular}{|l|l|}
\hline \multicolumn{1}{|c|}{$\begin{array}{c}\text { Buyer's } \\
\text { Characteristics }\end{array}$} & \multicolumn{1}{|c|}{$\begin{array}{c}\text { Buyer's Decision } \\
\text { Process }\end{array}$} \\
\hline $\begin{array}{l}\text { Cultural KA } \\
\text { Social }\end{array}$ & $\begin{array}{l}\text { Problem search } \\
\text { Information search }\end{array}$ \\
Personal & Evaluation of alternatives \\
Psychological & Purchase decision \\
& Postpurchase behaviour \\
\hline
\end{tabular}

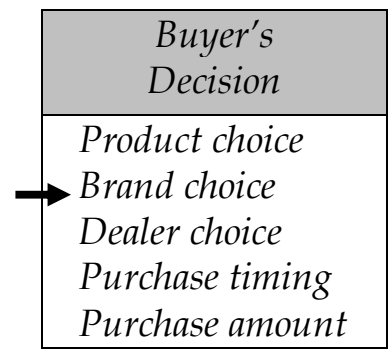

Gambar 1: Model Perilaku Pembeli

Sumber: Kotler (2000: 161).

Berdasarkan Gambar 1 di atas, Kotler (2000:161) mengemukakan bahwa rangsangan pemasaran terdiri dari produk, harga, tempat, dan promosi. Adapun rangsangan lain terdiri dari kekuatan dan peristiwa besar dalam lingkungan pembeli seperti ekonomi, teknologi, politik, dan budaya. Semua rangsangan ini dapat menghasilkan serangkaian tanggapan pembeli yang terdiri dari pemilihan produk, pemilihan merek, atau jenis, pemilihan pemasok, penentuan saat pembelian, dan jumlah pembelian. Tanggapan yang diberikan pembeli ini berdasarkan dari pengolahan rangsangan pemasaran maupun rangsangan lainnya. Terlihat bahwa di dalam keputusan untuk membeli suatu produk tertentu, maka konsumen dipengaruhi oleh beberapa rangsangan seperti produk, harga, tempat, dan promosi. Dari model perilaku pembeli tersebut di atas secara ringkas dapat dikatakan bahwa dalam mempelajari keputusan konsumen haruslah dilihat dari beberapa aspek yang mempengaruhi baik tentang sesuatu yang digagas, karakteristik, lingkungan maupun rangsangan pemasaran yang ditawarkan 


\section{E. Theory of Reasoned Action}

Salah satu teori yang biasa menerangkan hubungan antara sikap, minat dan perilaku adalah theory of reasoned action yang dikembangkan oleh Fishbein. Seseorang sangat tergantung pada sikap dan norma subyektif atas perilaku. Pada sisi lain keyakinan (beliving) atas akibat perilaku sangat mempengaruhi sikap dan norma subjektif.

Peter dan Olson (2000:147), menyatakan bahwa "teori tindakan beralasan (theory of reasoned action) mengasumsikan bahwa konsumen secara sadar mempertimbangkan konsekuensi alternatif perilaku yang sedang dipertimbangkan dan memilih salah satu yang dapat memberikan konsekuensi paling diharapkan".

Berdasarkan pengertian di atas, dapat dinyatakan bahwa teori tindakan beralasan merupakan kesadaran konsumen berperilaku dan memilih salah satu produk/ jasa yang sesuai kebutuhan dan keinginannya. Tindakan seseorang terhadap suatu objek tidak harus secara kuat atau tersistematisasi berhubungan dengan perilaku khusus mereka. Sebaliknya, penentu langsung apakah konsumen terlibat dalam perilaku adalah keinginan mereka untuk terlibat dalam perilaku tersebut. Fisbein memodifikasi serta memperluas model sikap multiciri dan mengkaitkan kepercayaan dan sikap konsumen pada keinginan berperilaku digambarkan sebagai berikut:

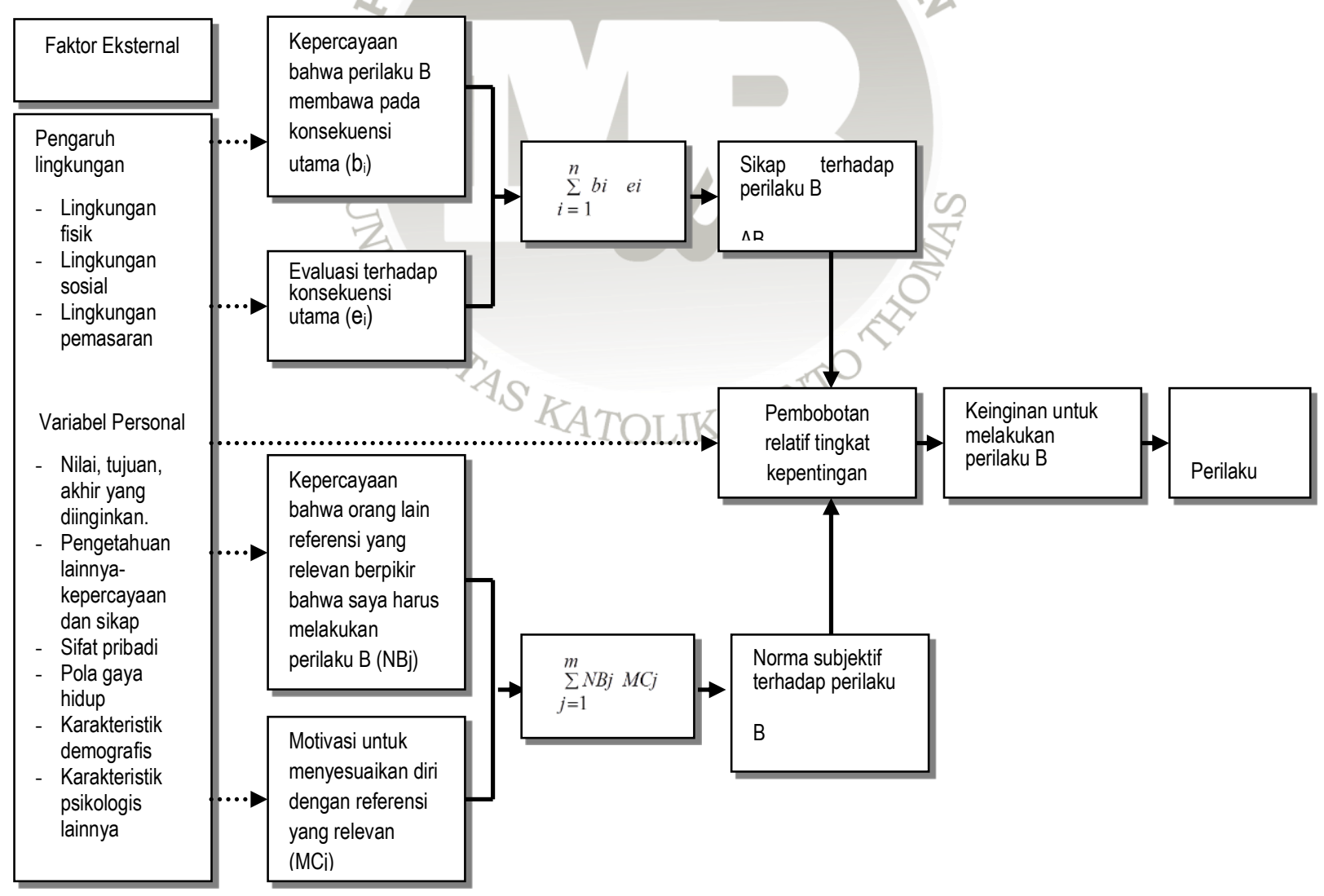

Gambar 2: Theory of Reasoned Action (Teori Tindakan Beralasan)

Sumber : Peter dan Olson. 2000:148).

Berdasarkan gambar 2, maka komponen-komponen model theory of reasoned action (teori tindakan beralasan) adalah:

\section{F. Sikap Konsumen}


Sikap (attitude) digunakan pertama kali oleh Herbert Spencer yang diartikan sebagai status mental seseorang. Telah ditemukan lebih dari tiga puluh definisi sikap yang dimasukkan ke dalam salah satu di antara kerangka pemikiran (Peter dan Olson, 2000:132) adalah:

a. Sikap adalah suatu bentuk evaluasi atau reaksi perasaan. Sikap seseorang terhadap suatu objek adalah perasaan mendukung atau memihak maupun perasaan tidak mendukung atau tidak memihak pada objek tersebut. Secara spesifik diformulasikan sikap sebagai derajat efek positif atau efek negatif terhadap suatu objek psikologis.

b. Sikap merupakan suatu kesiapan untuk bereaksi terhadap suatu objek dengan cara-cara tertentu. Kesiapan yang dimaksudkan merupakan kecenderungan potensial untuk bereaksi dengan cara tertentu apabila individu dihadapkan pada suatu stimulus yang menghendaki adanya respon.

c. Sikap merupakan konstelasi komponen-komponen kognitif, afektif dan konatif yang saling beriteraksi dalam memahami, merasakan dan berperilaku terhadap suatu objek.

Sikap sebagai keteraturan tertentu dalam hal perasaan (afeksi), pemikiran (kognitif) dan predisposisi tindakan (konatif) seseorang terhadap suatu aspek di lingkungan sekitarnya.

Menurut Boyd, dkk., (2000:135) "sikap adalah perasaraan positif atau negatif tentang suatu objek (katakanlah, sebuah merek) yang mempengaruhi seseorang untuk berperilaku dalam cara tertentu terhadap objek itu".

Pada umumnya, sikap digunakan untuk menilai efektivitas kegiatan pemasaran. Sikap merupakan evaluasi menyeluruh yang memungkinkan orang merespon secara konsisten berkenaan dengan objek atau alternatif pilihan yang diberikan. Sikap menempatkan seseorang ke dalam satu pikiran untuk menyukai atau tidak menyukai sesuatu, bergerak mendekati atau menjauhi sesuatu tersebut. Ada kecenderungan untuk menganggap bahwa sikap merupakan faktor yang tepat untuk meramalkan perilaku pembeli di masa mendatang. Jadi dengan memperlajari sikap, seseorang dapat menentukan apa yang akan dilakukan. Menurut Umar (2001:62), karakteristik sikap, yaitu :

a. Memiliki objek atau tujuan. Sikap berhubungan dengan orang atau objek tertentu. Sikap merupakan reaksi dari tindakan seseorang atau keadaan objek tertentu. Objek ini bisa membentuk suatu tindakan, seperti menentukan tempat di mana membeli produk.

b. Memiliki petunjuk, derajat dan intensitas. Sikap menunjukkan apa yang dirasakan seseorang terhadap objek, misalnya senang atau tidak senang terhadap objek. Derajat menunjukkan seberapa besar orang tersebut suka atau tidak suka akan objek. Sedangkan intensitas untuk menunjukkan suatu tingkat keyakinan atau kepercayaan terhadap objek.

c. Memiliki struktur. Sikap cenderung tetap dan mungkin berubah dan biasanya tidak cepat. Sikap yang dekat dengan pusat struktur ini berarti mempunyai derajat sentrabilitas yang tinggi dan sebaliknya. Struktur sikap mempunyai tiga komponen, yaitu: komponen pengetahuan, emosi dan kecenderungan perilaku.

d. Dapat dipelajari. Sebuah sikap merupakan hasil sebuah proses belajar yang didahului oleh seorang individu. Sikap dapat bersumber dari pengalaman pribadi dan kelompok. Salah satu fungsi sikap adalah fungsi penyesuaian yang meliputi: mengarahkan pada objek yang menyenangkan, menghindari objek yang tidak menyenangkan, dan penyesuaian sikap terhadap persepsi mereka terhadap sesuatu objek tertentu.

Sikap konsumen diukur dari keyakinan dan evaluasi atribut. Keyakinan akan atribut (bi) berisikan aspek pengetahuan tentang perilaku tertentu. Kalau dikaitkan dengan perilaku membeli, maka komponen ini selain berisikan pengetahuan tentang sikap membeli, komponen ini juga berisikan pengetahuan tentang konsekuensi positif atau negatif yang dapat diperoleh. Keyakinan tersebut dapat muncul dari dua sumber yaitu keyakinan yang muncul dari adanya informasi tentang objek yang diperoleh dari berbagai sumber informasi misalnya 
surat kabar, majalah, brosur, iklan dan lain-lain. Keyakinan juga berarti pengetahuan seseorang terhadap berbagai aspek dari suatu objek sikap.

Evaluasi atribut (ei) berkaitan dengan penilaian yang diberikan oleh seseorang terhadap tiap-tiap akibat atau konsekuensi yang dapat diperoleh dimana evaluasi tersebut dapat bersifat baik atau tidak baik, positif atau negatif, setuju atau tidak setuju dan lain-lain. Dalam kaitannya dengan masuk BPJS Kesehatan misalnya, maka evaluasi tentang akibat menunjukkan sejauh mana tiap-tiap akibat yang dapat diperoleh dari membeli produk, maka semakin positiflah sikap konsumen dan membeli suatu produk. Secara matematis dapat diekspresikan dalam bentuk persamaan sebagai berikut :

$$
A b=\sum_{t=1}^{n} \text { bi.ei }
$$

Dimana: $\mathrm{Ab}=$ Sikap konsumen terhadap atribut. $\mathrm{bi}=$ Keyakinan akan perilaku

$\mathrm{ei}=$ Evaluasi terhadap atribut $\mathrm{i} . \mathrm{n}=$ Jumlah responden (sampel)

$\mathrm{i}=$ Norma Subjektif

Norma subjektif dipengaruhi oleh kelompok preferen dan motivasi dari orang lain. Segala sesuatu mengandung nilai, jika bagi seseorang tidak, mungkin bagi orang lain. Berdasarkan anggapan ini, seseorang melakukan sesuatu karena pertimbangan kebutuhan, moral atau kesadaran etik dan pertimbangan logika.

Menurut Ndraha (2002:18), "sesuatu yang oleh seseorang dianggap dapat memenuhi kebutuhannya pada suatu waktu dan oleh karena itu ia berkepentingan atasnya". Oleh karena itu ia dicari, diburu dan dikejar dengan menggunakan berbagai cara dan alat. Dalam hubungan itu, nilai dianggap subjektif dan ekstrinsik. Nilai ekstrinsik suatu barang berbeda menurut seseorang dibanding dengan orang lain. Oleh karena itu, diupayakan agar nilai dapat diukur berdasarkan tolak ukur, standar yang objektif, yang disepakati bersama atau ditetapkan oleh lembaga yang berwenang. Norma subjektif dipengaruhi oleh:

\section{G. Keyakinan normatif dari kelompok preferen (NBj)}

Keyakinan normatif (NBj) adalah gagasan yang diterima dari kelompok referen yang berpendapat bahwa seyogyanya atau tidak seyogyanya untuk membeli suatu produk. Pandangan orang lain (preferen) dalam penelitian ini adalah pandangan anggota keluarga, saudara, teman-teman, dan iklan promosi. Pandangan ini tidak ditanyakan langsung kepada orang yang berpengaruh tersebut, tetapi ditanya kepada individu yang menjadi responden. Pendapat ini hanyalah sekedar persepsi individu tentang bagaimana pandangan orang lain, Mendukung atau tidak mendukung konsumen untuk membeli suatu produk.

\section{H. Motivasi dari kelompok preferen (MCj)}

Motivasi (MCj) adalah dorongan yang kuat, untuk menuruti pengaruh kelompok referen untuk membeli suatu produk. Dalam kaitannya dengan membeli suatu produk, maka komponen ini menyangkut kesediaan konsumen untuk mengikut/tidak mengikuti anggota keluarga, saudara, teman-teman, dan iklan promosi dalam membeli produk tersebut.

Motivasi seseorang untuk menuruti pendapat orang lain (preferen) ditentukan oleh kekuatan dari preferen bersangkutan yang dapat diartikan bahwa semakin kuat/lemah pula motivasinya untuk menuruti apa yang dikehendaki preferen, karakteristik personal dapat diartikan bahwa kesediaan seseorang itu untuk menuruti pendapat preferen tertentu pada kepribadian individu yang bersangkutan. Secara matematis norma subjektif dapat dihitung dengan rumus:

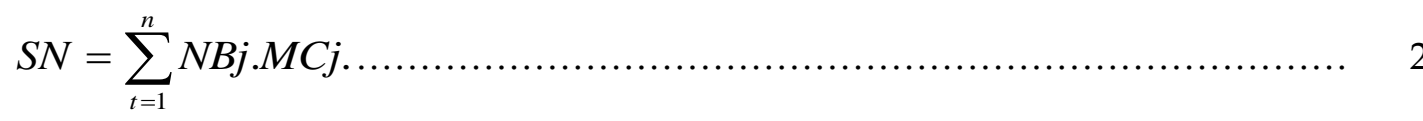

Dimana: $\mathrm{SN}=$ Norma subjektif yang menghendaki perilaku tertentu 
$\mathrm{NBj}=$ Keyakinan normatif dari pengaruh kelompok preferen

$\mathrm{MC} \mathrm{j}=$ Motivasi menurut preferen. $\mathrm{n}=$ Jumlah responden (jumlah sampel)

$\mathrm{i}=$ Minat Berperilaku

Menurut Sutisna (2001:99), minat adalah kecenderungan memberikan tanggapan pada suatu objek atau kelompok objek baik disenangi atau tidak disenangi secara konsisten". Dapat disimpulkan bahwa minat merupakan kecenderungan memberikan tanggapan pada suatu objek yang bersifat konsisten karena merasa tertarik. Dengan demikian, konsumen mengevaluasi merek tertentu secara keseluruhan dari yang paling jelek sampai yang paling baik. Maksud perilaku berisikan minat untuk melakukan perilaku tertentu. Secara teoritis terbentuknya minat ditentukan oleh interaksi antara tiga komponen yang mendahuluinya yaitu sikap konsumen dan norma subjektif.

Perilaku menggambarkan perilaku tertentu, misalnya membeli produk tertentu. Perilaku di sini menunjukkan minat/niat perilaku yang sudah direalisasi dalam bentuk tingkah laku yang tampak.

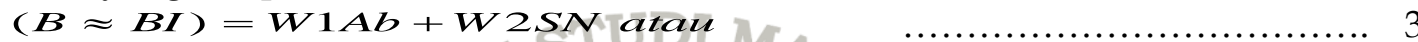

$$
\begin{aligned}
& =W 1 \sum b i \cdot e i+W 2 \sum N B j \cdot M C j
\end{aligned}
$$

Dimana: $\mathrm{B} \approx \mathrm{BI}=$ Minat konsumen untuk membeli. $\mathrm{Ab}=$ Sikap konsumen

$\mathrm{SN}=$ Norma subjektif yang menghendaki perilaku tertentu

$\mathrm{W} 1, \mathrm{~W} 2$ = Bobot yang ditentukan secara empiris yang menggambarkan pengaruh relatif dari komponen.

Komponen ini menggambarkan perilaku tertentu, yang menunjukkan minat/niat perilaku yang sudah direalisasikan dalam bentuk tingkah laku yang tampak. Pada teory of reasoned action menjelaskan perilaku dengan mengidentifikasi variabel-variabel yang mendukung tindakan, tetapi variabel yang dianggap mempunyai pengaruh langsung adalah niat.

\section{METODOLOGI PENELITIAN}

Dalam penelitian ini, yang menjadi objek penelitian adalah Theory Of Reasoned Action sebagai variabel independen dengan sub variabelnya terdiri dari Sikap Masyarakat $(\mathrm{Ab})$, Norma Subjektif (SN), Sedangkan variabel dependennya adalah Memprediksi Minat Masyarakat yang terdiri dari Minat berperilaku (BI)

Mengingat sifat penelitian (the purpose of study) adalah deskriptif yang dilaksanakan melalui pengumpulan data di lapangan, maka metode penelitian yang digunakan adalah metode descriptive survey dan metode explanatory survey. Metode descriptive survey dilakukan yang bertujuan untuk memperoleh data pada objek yang diteliti. Sedangkan metode explanatory survey dilakukan yang bertujuan untuk menggali dan mengungkapkan masalah dalam penelitian ini. Unit analisis (unit of analysis) dari penelitian ini adalah peserta Mandiri BPJS Kesehatan di Kecamatan Medan Selayang.

\section{A. Metode Penarikan Sampel}

Populasi dalam penelitian ini adalah seluruh masyarakat Kecamatan Medan Selayang. Sampel adalah bagian dari populasi. Penentuan sampel dilakukan secara insidental yaitu kuesioner diberikan pada masyarakat yang bertemu dengan peneliti pada saat penelitian dilakukan di lokasi penelitian, dengan teknik Sampling digambarkan sebagai berikut: 


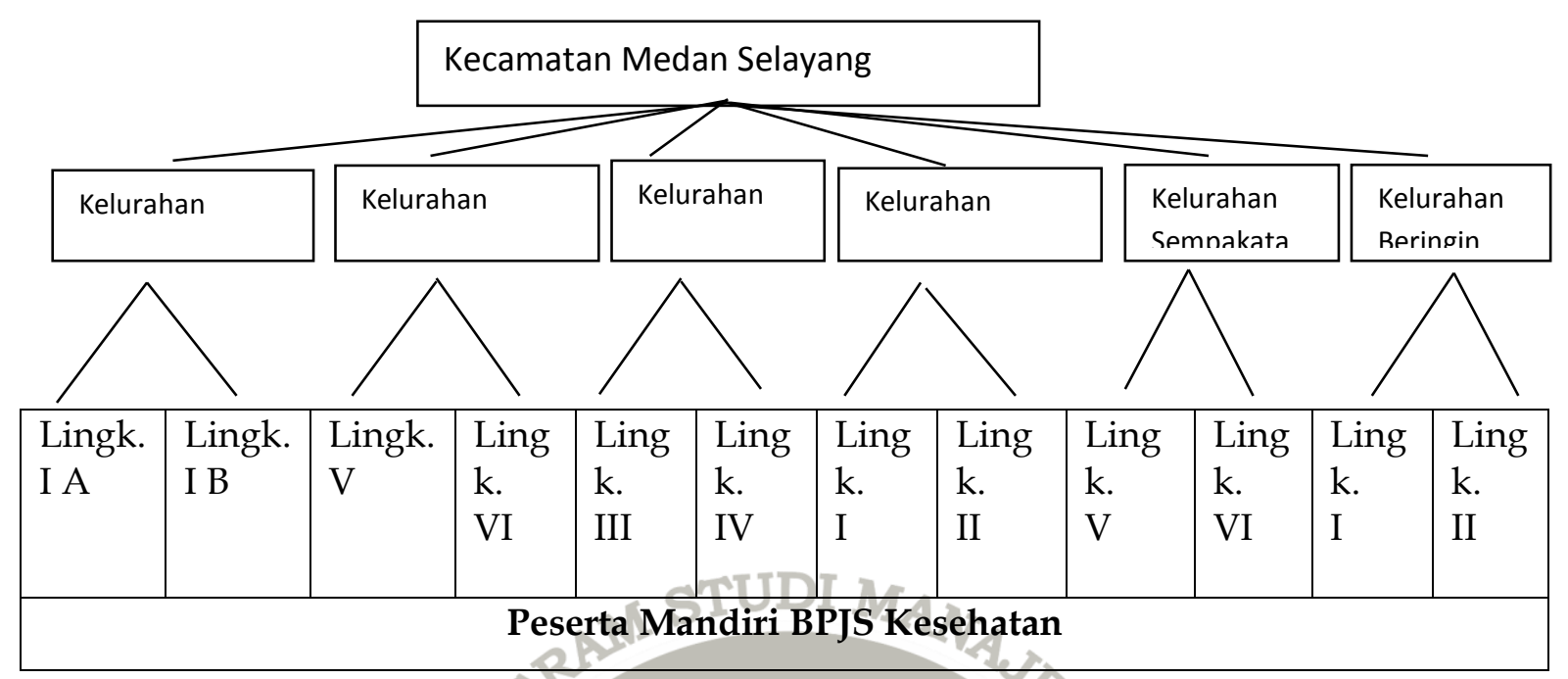

Gambar 3: Skema Rancangan Sampling

Sumber: Kantor Camat Medan Selayang Kota Medan

Berdasangankan skema rancangan sampling di atas, maka untuk jumlah Sampel penelitian ditentukan berdasarkan kesalahan (sampling error) maksimum yang diinginkan, dengan rumus (Supranto, 2009:113):

$$
n=\left(\frac{Z_{\alpha / 2}{ }^{2} \times \sigma}{\varepsilon}\right)^{2}=\left(\frac{1,96 \times 0,5}{0,1}\right)^{2}=96 \text { orang } \ldots \ldots \ldots \ldots \ldots \ldots \ldots . . . . . . . . .4
$$

Dalam penelitian ini, tingkat keyakinan ditetapkan $95 \%\left(\alpha=5 \%\right.$, sehingga $\left.Z^{1 / 2} \alpha=1,96\right)$, kesalahan (error) maksimum $(\varepsilon)=0,1$ dan standar deviasi $(\sigma)=0,5$; maka jumlah sampel yang dibutuhkan $(n)=96,04$ dibulatkan menjadi 96 orang.

\section{B. Operasionalisasi Variabel}

Operasionalisasi variabel merupakan batasan pokok pembahasan yang akan diteliti. Adapun variabel yang akan diteliti sebagai berikut:

1. Sikap konsumen $(\mathrm{Ab})$ perilaku yang diukur dari: Keyakinan (bi), Evaluasi akibat (ei) dengan indikator Jumlah Iuran/ premi lebih murah, Tersedia pilihan jumlah premi, Jumlah premi tentukan kelas, Kemudahan syarat menjadi peserta, Manfaat perlindungan kesehatan, Pelayanan Kesehatan dijamin oleh Pemerintah, Biaya pengobatan ditanggung oleh Pemerintah, Tersedia banyak RS Sakit sebagai Mitra

2. Norma subjektif (SN) minat yang diukur dari: Keyakinan normatif (NBj) dan . Motivasi (MCj) dengan indikator Anggota keluarga Saudara, Tetangga, Teman-teman, Iklan-promosi

3. Minat berperilaku (BI) diukur dari perhatian/ kecenderungan seseorang, dengan indikator Anggota keluarga Saudara, Tetangga, Teman-teman, Iklan-promosi

Pengukuran variabel penelitian mengacu pada skala Thurstone dengan tujuh tingkatan jawaban yaitu: sangat tidak setuju (STS), tidak setuju (TS), agak tidak setuju (ATS), netral, agak setuju (AS), setuju (S), sangat setuju (SS). Dengan skor -3, -2, -1, 0, 1, 2, 3. Untuk menghindari kecenderungan sentralisasi maka alternatif jawaban yang netral (skor nol) tidak digunakan dalam kuesioner.

\section{Teknik Pengumpulan Data}

Teknik pengumpulan data yang digunakan adalah kuesioner. Kuesioner dilakukan dengan membagikan angket kepada responden di Kecamatan Medan Selayang yang 
berhubungan dengan sikap dan norma subjektif. Daftar kuesioner dibuat dalam bentuk pertanyaan dengan mencantumkan beberapa pilihan jawaban dan responden memilih salah satu jawaban yang paling tepat. Setelah daftar kuesioner diisi, kemudian dikumpulkan kembali untuk dianalisis lebih lanjut.

\section{Metode Analisis}

\section{a. Uji Validitasi}

Uji validitas berguna untuk menguji ketepatan hasil kuesioner. Dalam hal ini teknik korelasi untuk menentukan validitas item ini sampai sekarang merupakan teknik yang paling banyak digunakan. Selanjutnya dalam memberikan interprestasi terhadap koefisien korelasi, dimana item yang mempunyai korelasi positif dengan kriteria (skor total) serta korelasi yang tinggi pula.

Menurut Sugiyono (2005:114)."jumlah anggota sampel digunakan sekitar 30 orang". Biasanya, syarat minimum yang dianggap memenuhi syarat adalah kalau $r=0,3$. Jadi, jika korelasi antara butir dengan skor total kurang dari 0,3, maka butir dalam instrumen tersebut dinyatakan tidak valid. Untuk menghitung koefisien korelasi digunakan Corrected Item-Total Correlation.

\section{b. Uji Reliabilitas}

Menurut Sugiyono (2005:122), "pengujian reliabilitas dengan internal consistency, dilakukan dengan cara mencoba instrumen sekali saja, kemudian data yang diperoleh dianalisis dengan teknik tertentu". Hasil analisis dapat digunakan untuk memprediksi reliabilitas instrumen. Pengujian realibilitas instrumen dapat Cronbach's Alpha if Item Deleted. Pada pengujian ini dinilai reliabel jika reliabilitas hitung lebih besar dari 0,50 di mana kriteria sebagai berikut: jika $\alpha>0,50$ artinya instrumen reliabel, dan jika $\alpha<0,50$ artinya instrumen tidak reliabel

\section{c. Model Theory of Reasoned Action}

Teknik analisis data yang dilakukan dalam penelitian ini adalah model theory of reasoned action, yaitu (Peter dan Olson, 2000:148)

a. Sikap konsumen $(\mathrm{Ab})$, dihitung dengan rumus:

$$
\mathrm{Ab}=\sum_{t=1}^{n} \text { bi.ei }
$$

Di mana $: \mathrm{Ab}=$ Sikap total individu terhadap objek tertentu

bi = Kekuatan keyakinan konsumen bahwa objek memiliki atribut i

ei $=$ Evaluasi individu mengenai atribut $\mathrm{i}$

$\mathrm{n}=$ Jumlah kriteria atribut yang relevan

b. Norma Subjektif (SN), dihitung dengan rumus:

$$
S N=\sum_{t=1}^{n} N B j . M C j
$$

Dimana $: \mathrm{SN}=$ Norma subjektif $. \mathrm{NBj}=$ Keyakinan normatif individu

$$
\mathrm{MCj}=\text { Motivasi konsumen. } \mathrm{n}=\text { Banyaknya referen yang relevan }
$$

c. Minat berperilaku (BI)

$(B \approx B I)=W 1 A b+W 2 S N$ atau

$$
\begin{aligned}
& =W 1 \sum \text { bi.ei }+W 2 \sum N B j . M C j
\end{aligned}
$$

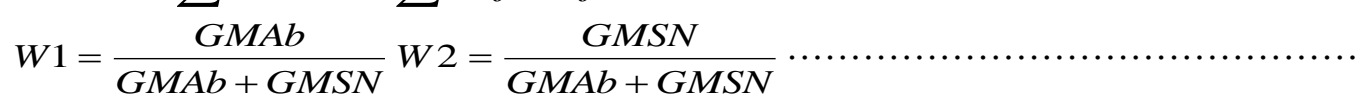

Di mana: 
Volume 17 Nomor 2

$G M A b=\frac{\text { Total } b_{i}+\text { Total } e_{i}}{2 \times \text { Jumlah atribut }} G M S N=\frac{\text { Total } N B j+\text { Total } M C j}{2 \times \text { Jumlah atribut }}$

Dimana $: \mathrm{B}=$ perilaku. $\mathrm{BI}=$ maksud perilaku. $\mathrm{Ab}=$ Sikap terhadap pelaksanaan perilaku,

B.SN $=$ Norma subjektif

$\mathrm{W} 1, \mathrm{~W} 2$ = Bobot yang ditentukan secara empiris yang menggambarkan

pengaruh relatif dari komponen sikap dan norma subjektif.

Kriteria pengujian skor sikap konsumen dan norma subjektif terhadap minat

masuk BPJS Kesehatan digunakan range Henerson sebagai berikut :

$1,8<\mathrm{Ab} / \mathrm{SN} \leq 3,0$ (Sangat kuat/positif). 0,6 $<\mathrm{Ab} / \mathrm{SN} \leq 1,8$ (Kuat/positif)

$-0,6<\mathrm{Ab} / \mathrm{SN} \leq 0,6$ (Cukup kuat). $-1,8<\mathrm{Ab} / \mathrm{SN} \leq-0,6$ (Lemah/negatif)

$-3,0<\mathrm{Ab} / \mathrm{SN} \leq-1,8$ (Sangat lemah/negatif)

\section{HASIL PENELITIAN DAN PEMBAHASAN}

\section{A. Hasil Penelitian}

a. Uji Validitasi dan Uji Reliabilitas

Hasil pengujian terhadap validitas dan reabilitas menunjukkan bahwa indikator minat menjadi peserta mandiri BPJS Kesehatan Masyarakat Medan Selayang sudah valid reliable, karena dilihat dari nilai korelasi hitung semua di atas 0,3 dan nilai Cronbach's Alpha if Item Deleted lebih besar dari 0,5

\section{b. Identitas Responden}

Identitas responden dilihat dari jenis kelamin, umur, pendidikan dan pekerjaan responden. Jumlah dan prosentasinya disajikan pada tabel berikut:

Tabel 1: Jenis Kelamin Responden

\begin{tabular}{|l|c|c|}
\hline Jenis Kelamin Responden & Jumlah & Persen (\%) \\
\hline Wanita & 39 & 40.6 \\
\hline Pria & 57 & 59.4 \\
\hline Jumlah & 96 & 100 \\
\hline
\end{tabular}

Sumber: Diolah dari hasil kuesioner

\section{KATOT}

Dari tabel di atas ditunjukkan bahwa dari 96 responden diketahui berjenis kelamin wanita 39 orang $(40.6 \%)$ sedangkan pria 57 orang (59.4\%). Dengan demikian, responden mayoritas berjenis kelamin laki-laki.

Tabel 2: Jenis Umur Responden

\begin{tabular}{|c|c|c|}
\hline Umur Responden & Jumlah & Persen (\%) \\
\hline$<17$ tahun & 1 & 1.04 \\
\hline 17 - 31 tahun & 11 & 11.5 \\
\hline 32 - 46 tahun & 36 & 37.5 \\
\hline$>46$ tahun & 48 & 50 \\
\hline Total & 96 & 100 \\
\hline
\end{tabular}

Sumber: Diolah dari hasil kuesioner

Dari tabel di atas ditunjukkan bahwa dari 96 responden diketahui berumur 17 tahun ke bawah sebanyak 1 orang (1.04\%), antara 17-31 tahun sebanyak 11 orang (11.5\%), antara 3246 sebanyak 36 orang (37.5\%), diatas 46 tahun sebanyak 48 orang (50\%). Dengan demikian, responden Mandiri berencana masuk BPJS Kesehatan diatas 46 tahun sebanyak 48 orang.

Tabel 3: Pendidikan Responden

\begin{tabular}{|l|c|c|}
\hline Pendidikan Responden & Jumlah & Persen (\%) \\
\hline SD & 4 & 4.17 \\
\hline
\end{tabular}




\begin{tabular}{|l|c|c|}
\hline SLTP & 15 & 15.6 \\
\hline SMA/sederajat & 40 & 41.7 \\
\hline Perguruan tinggi & 37 & 38.5 \\
\hline Jumlah & 96 & 100 \\
\hline
\end{tabular}

Sumber: Diolah dari hasil kuesioner

Berdasarkan tabel di atas, ditunjukkan bahwa dari 96 responden diketahui berpendidikan Sekolah Dasar sebanyak 4 orang (4.17\%), SLTP sebanyak 15 orang (15.6 \%), SMU/sederajat sebanyak 40 orang $(41.7 \%)$ dan responden sedang kuliah atau lulusan Perguruan Tinggi sebanyak 37 orang $(38.5 \%)$. Dengan demikian, responden mayoritas berpendidikan SMU sebanyak 40 orang

Tabel 4: Pekerjaan Responden

\begin{tabular}{|l|c|c|}
\hline Pekerjaan Responden & Jumlah & Persen (\%) \\
\hline Wiraswasta & 34 & 35.4 \\
\hline Pegawai Swasta SIU & 23 & 24 \\
\hline Ibu Rumah Tangga & 25 & 26 \\
\hline Bertani & 6 & 6.25 \\
\hline Tukang & 8 & 8.33 \\
\hline Jumlah & 96 & 100 \\
\hline
\end{tabular}

Sumber: Diolah dari hasil kuesioner

Berdasarkan tabel di atas, ditunjukkan bahwa dari 96 responden yang berwiraswasta sebanyak 34 orang (35.4\%), Pegawai Swasta sebanyak 23 orang (24\%), Ibu Rumah Tangga sebanyak 25 orang $(26 \%)$ Bertani sebanyak 6 orang $(6.26 \%)$, Tukang sebanyak 8 orang $(8.33 \%)$.

Tabel 5: Jumlah Premi Responden

\begin{tabular}{|l|c|c|}
\hline Jumlah Premi (Rp) & Jumlah & Persen (\%) \\
\hline $25.000,-$ & 27 & 28.1 \\
\hline $42.500,-$ & 43 & 44.8 \\
\hline $59.500,-$ & 27.1 \\
\hline
\end{tabular}

Sumber: Diolah dari hasil kuesioner

Berdasarkan tabel di atas, ditunjukkan bahwa dari 96 responden yang memilih jumlah premi paling banyak adalah premi Rp 42.500,- per bulan yaitu 43 orang (44.8\%) artinya perilaku masyarakat Medan Selayang memilih masuk menjadi peserta Mandiri BPJS Kesehatan dominan kelas ekonomi menengah ke bawah.

Tabel 6: Tujuan Menjadi Peserta BPJS Kesehatan

\begin{tabular}{|l|c|c|}
\hline Jumlah Premi (Rp) & Jumlah & Persen (\%) \\
\hline Untuk berobat gratis & 22 & 23 \\
\hline Kemudahan biaya karena dicicil & 38 & 40 \\
\hline Untuk Perlindungan Kesehatan & 36 & 37 \\
\hline
\end{tabular}

Sumber: Diolah dari hasil kuesioner

Berdasarkan tabel di atas, ditunjukkan bahwa dari 96 responden yang bertujuan masuk menjadi peserta Mandiri BPJS Kesehatan untuk berobat gratis 22 orang (23.8\%), kemudahan biaya karena dicicil melalui 38 orang (40\%), untuk perlindungan kesehatan 36 orang (37\%). 
Tabel 7: Informasi BPJS Kesehatan

\begin{tabular}{|l|c|c|}
\hline Sumber Informasi & Jumlah & Persen (\%) \\
\hline Keluarga & 43 & 45 \\
\hline Saudara & 7 & 7.3 \\
\hline Tetangga & 9 & 9.4 \\
\hline Teman & 15 & 16 \\
\hline Iklan TV & 22 & 23 \\
\hline
\end{tabular}

Sumber: Diolah dari hasil kuesioner

Berdasarkan tabel di atas, ditunjukkan bahwa dari 96 responden yang mendapatkan informasi tentang BPJS Kesehatan paling banyak adalah informasi dari keluarga yaitu sebesar 43 orang (45\%), dan informasi iklan TV sebesar 22 orang (23\%), artinya perliku Masyarakat Kecamatan Medan Selayang memilih masuk menjadi peserta Mandiri BPJS Kesehatan dominan dari iklan TV dan anggota keluarga, hal ini berhubungan dengan pengambilan keputusan setelah ada informasi berhubungan dengan kesehatan sebagai suatu kebutuhan, maka diputuskan secara bersama di dalam keluarga.

\section{B. Pembahasan}

\section{a. Variabel keyakinan akan perilaku (bi) / Sikap Konsumen}

Keyakinan akan perilaku (bi) merupakan variabel yang kekuatan tentang keyakinan Masyarakat Kecamatan Medan Selayang bahwa dengan masuk BPJS Kesehatan akan memperoleh manfaat tertentu. Manfaat tersebut adalah Jumlah premi lebih murah, tersedia pilihan jumlah premi, jumlah premi tentukan kelas, kemudahan syarat menjadi peserta, manfaat perlindungan kesehatan,pelayanan kesehatan dijamin oleh Pemerintah, biaya pengobatan ditanggung oleh Pemerintah, tersedia banyak Rumah Sakit sebagai Mitra. Nilai atribut dari variabel keyakinan akan perilaku Masyarakat Kecamatan Medan Selayang disajikan pada tabel 4

Tabel 8: Nilai Atribut dari Variabel Keyakinan Responden

\begin{tabular}{|c|c|c|c|c|c|c|c|c|c|c|c|c|}
\hline \multirow{2}{*}{$\begin{array}{l}\text { Sub } \\
\text { variabel }\end{array}$} & SS & $S$ & AS & ATS & TS & STS & \multirow{2}{*}{$\begin{array}{l}\text { Jlh } \\
\text { Resp }\end{array}$} & \multirow{2}{*}{+} & \multirow[b]{2}{*}{-} & \multirow{2}{*}{$\begin{array}{l}\text { +/- per } \\
\text { JlhResp }\end{array}$} & \multirow[b]{2}{*}{ R2T } & \multirow[t]{2}{*}{ Nilai } \\
\hline & 3 & 2 & 1 & $(-1)$ & $(-2)$ & $(-3)$ & & & & & & \\
\hline bi1 & 49 & 35 & 10 & 0 & 2 & 0 & 96 & 227 & 4 & 223 & 0.12 & Kuat+ \\
\hline bi2 & 40 & 45 & 11 & 0 & 0 & 0 & 96 & 221 & 0 & 221 & 0.12 & Kuat+ \\
\hline bi3 & 50 & 34 & 12 & 0 & 0 & 0 & 96 & 230 & 0 & 230 & 0.13 & Kuat+ \\
\hline bi4 & 40 & 45 & 9 & 2 & 0 & 0 & 96 & 219 & 2 & 219 & 1.94 & Kuat+ \\
\hline bi5 & 49 & 41 & 6 & 0 & 0 & 0 & 96 & 235 & 0 & 235 & 0.13 & Kuat+ \\
\hline bi6 & 42 & 43 & 11 & 0 & 0 & 0 & 96 & 223 & 0 & 223 & 1.99 & Kuat+ \\
\hline bi7 & 45 & 39 & 9 & 2 & 1 & 0 & 96 & 222 & 4 & 218 & 0.12 & Kuat+ \\
\hline \multirow[t]{3}{*}{ bi8 } & 50 & 35 & 11 & 0 & 0 & 0 & 96 & 231 & 0 & 231 & 0.13 & \\
\hline & \multicolumn{7}{|c|}{ Jumlah Rata-rata Tertimbang } & 1808 & 10 & 1798 & 4.68 & \\
\hline & \multicolumn{7}{|c|}{ Rata-rata bi } & & & & 0.15 & Kuat+ \\
\hline
\end{tabular}

Sumber: Diolah dari hasil kuesioner

Berdasarkan tabel di atas, menunjukkan keyakinan Masyarakat Kecamatan Medan Selayang mengenai atribut BPJS Kesehatan Rata-rata skor jawaban responden dihitung dengan cara membagi antara jumlah skor dengan jumlah sub variabel. Rata-rata tertimbang dihitung dengan cara mengalikan antara total jawaban responden untuk tiap alternatif dengan alternatif pilihan jawaban 
Arti penilaian sub variabel keyakinan akan perilaku $\left(b_{i}\right)$ sebagai berikut:

a. Sub variabel $\left(b_{1}\right)$ nilai 0.12 , berarti masyarakat Kecamatan Medan Selayang mempunyai keyakinan yang kuat (positif) karena Iuran/ premi BPJS lebih murah.

b. Sub variabel $\left(b_{2}\right)$ nilai 0.12 , berarti masyarakat Kecamatan Medan Selayang mempunyai keyakinan yang kuat (positif) bahwa dengan masuk BPJS Kesehatan, tersedia pilihan jumlah premi sesuai kemampuan.

c. Sub variabel $\left(b_{3}\right)$ nilai 0.13 , berarti masyarakat Kecamatan Medan Selayang mempunyai keyakinan yang kuat (positif) karena jumlah premi otomatis tentukan kelas rawat inap yang ditentukan oleh BPJS Kesehatan

d. Sub variabel $\left(b_{4}\right)$ nilai 1,94, berarti masyarakat Kecamatan Medan Selayang mempunyai keyakinan yang kuat (positif) karena kemudahan syarat masuk menjadi nasabah BPJS Kesehatan

e. Sub variabel $\left(b_{5}\right)$ nilai 0.13 , berarti masyarakat Kecamatan Medan Selayang mempunyai keyakinan yang kuat (positif) karena manfaat perlindungan kesehatan yang diberikan oleh BPJS Kesehatan.

f. Sub variabel $\left(b_{6}\right)$ nilai 1,99 , berarti masyarakat Kecamatan Medan Selayang mempunyai keyakinan yang kuat (positif) karena pelayanan kesehatan di jamin oleh Pemerintah.

g. Sub variabel $\left(b_{7}\right)$ nilai 0.12 , berarti masyarakat Kecamatan Medan Selayang mempunyai keyakinan yang kuat (positif) karena biaya pengobatan gratis ditanggung oleh Pemerintah

h. Sub variabel $\left(b_{8}\right)$ nilai 0.13 , berarti masyarakat Kecamatan Medan Selayang mempunyai keyakinan yang kuat (positif) karena tersedia banyak Rumah Sakit sebagai Mitra dari BPJS Kesehatan.

Dari Tabel 8, diketahui nilai rata-rata atribut dari variabel keyakinan responden 0.15. Artinya rata-rata masyarakat Kecamatan Medan Selayang mempunyai keyakinan yang kuat/positifadalah bermanfaat masuk menjadi peserta Mandiri BPJS Kesehatan untuk perlindungan kesehatan kelak jika kena penyakit untuk dapat berobat gratis atau biaya ditanggung oleh Pemerintah.

\section{b. Evaluasi (ei)}

Evaluasi $\left(e_{i}\right)$ merupakan variabel yang menunjukkan kepada Masyarakat Kecamatan Medan Selayang apakah masuk BPJS Kesehatan mempunyai manfaat baik atau bahkan sebaliknya tidak bermanfaat. Manfaat tersebut adalah: Jumlah premi lebih murah, tersedia pilihan jumlah premi, jumlah premi tentukan kelas, kemudahan syarat menjadi peserta, manfaat perlindungan kesehatan, pelayanan kesehatan dijamin oleh Pemerintah, biaya pengobatan ditanggung oleh Pemerintah, tersedia banyak Rumah Sakit sebagai Mitra. Nilai atribut dari variabel evaluasi Masyarakat Kecamatan Medan Selayang disajikan pada tabel berikut:

Tabel 9: Nilai Atribut dari Variabel Evaluasi Responden

\begin{tabular}{|c|c|c|c|c|c|c|c|c|c|c|c|c|}
\hline \multirow{2}{*}{$\begin{array}{l}\text { Sub } \\
\text { variabel }\end{array}$} & SS & $S$ & AS & ATS & TS & STS & \multirow{2}{*}{$\begin{array}{l}\text { Jlh } \\
\text { Resp }\end{array}$} & \multirow[b]{2}{*}{+} & \multirow[b]{2}{*}{ - } & \multirow{2}{*}{$\begin{array}{l}\text { +/- per } \\
\text { JlhResp }\end{array}$} & \multirow[b]{2}{*}{ R12T } & \multirow[t]{2}{*}{ Nilai } \\
\hline & 3 & 2 & 1 & $(-1)$ & $(-2)$ & $(-3)$ & & & & & & \\
\hline $\mathrm{e}_{1}$ & 48 & 36 & 12 & 0 & 2 & 0 & 96 & 228 & 0 & 228 & 0.13 & Kuat+ \\
\hline $\mathrm{e}_{2}$ & 39 & 41 & 14 & 0 & 0 & 0 & 96 & 213 & 4 & 209 & 0.12 & Kuat+ \\
\hline $\mathrm{e}_{3}$ & 45 & 36 & 15 & 0 & 0 & 0 & 96 & 222 & 0 & 222 & 0.13 & Kuat+ \\
\hline $\mathrm{e}_{4}$ & 41 & 41 & 14 & 0 & 0 & 0 & 96 & 219 & 0 & 219 & 0.12 & Kuat+ \\
\hline $\mathrm{e}_{5}$ & 51 & 36 & 9 & 0 & 0 & 0 & 96 & 234 & 0 & 234 & 0.13 & Kuat+ \\
\hline e6 & 47 & 37 & 12 & 0 & 0 & 0 & 96 & 227 & 0 & 227 & 0.13 & Kuat+ \\
\hline $\mathrm{e} 7$ & 47 & 32 & 12 & 1 & 4 & 0 & 96 & 217 & 9 & 208 & 0.12 & Kuat+ \\
\hline e8 & 52 & 29 & 15 & 0 & 0 & 0 & & 229 & 0 & 229 & 0.13 & Kuat+ \\
\hline
\end{tabular}


Volume 17 Nomor 2

\begin{tabular}{|l|l|l|l|l|l|l|l|l|r|r|r|l|}
\hline $\begin{array}{l}\text { Sub } \\
\text { variabel }\end{array}$ & SS & S & AS & ATS & TS & STS & Jlh & & & $\begin{array}{l}\text { +/- per } \\
\text { JlhResp }\end{array}$ & R12T & \\
\hline & $\mathbf{3}$ & $\mathbf{2}$ & $\mathbf{1}$ & $\mathbf{( - 1 )}$ & $\mathbf{( - 2})$ & $\mathbf{( - 3 )}$ & Resp & + & - & 1 & \\
\hline \multicolumn{6}{|l|}{} \\
\hline
\end{tabular}

Sumber: Diolah dari hasil kuesioner

Berdasarkan tabel di atas, menunjukkan evaluasi Masyarakat Kecamatan Medan Selayang mengenai atribut BPJS Kesehatan. Rata-rata skor jawaban responden dihitung dengan cara membagi antara jumlah skor dengan jumlah sub variabel. Rata-rata tertimbang dihitung dengan cara mengalikan antara total jawaban responden untuk tiap alternatif dengan alternatif pilihan jawaban.

Arti penilaian sub variabel evaluasi $\left(\mathrm{e}_{\mathrm{i}}\right)$ sebagai berikut:

a. Sub variabel $\left(\mathrm{e}_{1}\right)$ nilai 0,13 berarti masyarakat Kecamatan Medan Selayang memberikan evaluasi yang kuat (positif) karena dengan masuk BPJS Kesehatan preminya lebih murah dibandingkan dengan ansuransi lain..

b. Sub variabel $\left(\mathrm{e}_{2}\right)$ nilai 0,12 berarti masyarakat Kecamatan Medan Selayang memberikan evaluasi yang kuat (positif) atas tersedianya pilihan jumlah premi bagi para masyarakat yang masuk BPJS Kesehatan.

c. Sub variabel $\left(e_{3}\right)$ nilai 0,13 berarti masyarakat Kecamatan Medan Selayang memberikan evaluasi yang kuat (positif) karena jumlah premi otomatis tentukan kelas rawar inap.

d. Sub variabel $\left(\mathrm{e}_{4}\right)$ nilai 0,12 berarti masyarakat Kecamatan Medan Selayang memberikan evaluasi yang kuat (positif) karena kemudahan syarat masuk menjadi peserta BPJS Kesehatan.

e. Sub variabel ( $\left.e_{5}\right)$ nilai 0,13 berarti masyarakat Kecamatan Medan Selayang memberikan evaluasi yang kuat (positif) atas perlindungan kesehatan.

f. Sub variabel $\left(\mathrm{e}_{6}\right)$ nilai 0,12 berarti masyarakat Kecamatan Medan Selayang memberikan evaluasi yang kuat (positif) atas pelayanan kesehatan yang dijamin oleh Pemerintah

g. Sub variabel (e $e_{7}$ ) nilai 0,13 berarti masyarakat Kecamatan Medan Selayang memberikan evaluasi yang kuat (positif) atas biaya pengobatan gratis ditanggung oleh Pemerintah.

h. Sub variabel (es) nilai 0,13 berarti masyarakat Kecamatan Medan Selayang memberikan evaluasi yang kuat (positif) atas tersedianya banyak Rumah Sakit sebagai Mitra BPJS Kesehatan.

Berdasarkan tabel 4.12 diketahui nilai rata-rata atribut dari variabel evaluasi Masyarakat Kecamatan Medan Selayang berminat masuk menjadi peserta Mandiri BPJS Kesehatan adalah sebesar 1,13. Artinya, rata-rata Masyarakat Kecamatan Medan Selayang memberikan evaluasi yang positif (kuat) bermanfaat untuk masuk BPJS Kesehatan untuk motivasi perlindungan kesehatan yang preminya dicicil lebih dahulu sebagai proteksi jika kelak sakit.

\section{c. Nilai Sikap Konsumen (Ab).}

Sikap konsumen $(\mathrm{Ab})$ merupakan variabel yang menunjukkan sikap responden terhadap minat membeli BPJS Kesehatan. Sikap responden terhadap manfaat masuk BPJS Kesehatan karena: Jumlah premi lebih murah, tersedia pilihan jumlah premi, jumlah premi tentukan kelas, kemudahan syarat menjadi peserta, manfaat perlindungan kesehatan, pelayanan kesehatan dijamin oleh Pemerintah, biaya pengobatan ditanggung oleh Pemerintah, tersedia banyak Rumah Sakit sebagai Mitra . Nilai atribut dari variabel sikap Masyarakat Kecamatan Medan Selayang disajikan pada tabel berikut: 
Tabel 10: Nilai Sikap Responden

\begin{tabular}{|c|c|c|c|c|}
\hline $\begin{array}{c}\text { Sub } \\
\text { variabel }\end{array}$ & $\begin{array}{c}\text { Keyakinan } \\
\text { (bi) }\end{array}$ & $\begin{array}{c}\text { Evaluasi } \\
(\mathbf{e i})\end{array}$ & $\begin{array}{c}\text { Sikap masyarakat } \\
\mathbf{( A b )} \\
\mathbf{( b i} \mathbf{~} \mathbf{~ e i})\end{array}$ & Penilaian \\
\hline $\mathrm{Ab}_{1}$ & 0.12 & 0.13 & 0.12 & Kuat/positif \\
\hline $\mathrm{Ab}_{2}$ & 0.12 & 0.12 & 0.01 & Kuat/positif \\
\hline $\mathrm{Ab}_{3}$ & 0.13 & 0.13 & 0.02 & Kuat/positif \\
\hline $\mathrm{Ab}_{4}$ & 1.94 & 0.12 & 0.24 & Kuat/positif \\
\hline $\mathrm{Ab} b_{5}$ & 0.13 & 0.13 & 0.02 & Kuat/positif \\
\hline $\mathrm{Ab} b_{6}$ & 1.99 & 0.13 & 0.25 & Kuat/positif \\
\hline $\mathrm{Ab} b_{7}$ & 0.12 & 0.12 & 0.01 & Kuat/positif \\
\hline $\mathrm{Ab} b_{8}$ & 0.13 & 0.13 & 0.02 & Kuat/positif \\
\hline $\begin{array}{c}\text { Jumlah } \\
\text { Rata-rata }\end{array}$ & 4.68 & 1 & 0.59 & - \\
\cline { 2 - 5 } & 0.59 & 0.13 & 0.07 & Kuat/positif \\
\hline
\end{tabular}

Sumber: Diolah dari hasil kuesioner

Tabel di atas menunjukkan keterangan mengenai kuat tidaknya pengaruh sikap Masyarakat Kecamatan Medan Selayang dengan mengalikan antara nilai keyakinan akan perilaku (bi) dengan variabel evaluasi $\left(\mathrm{e}_{\mathrm{i}}\right)$. Dari tabel tersebut terlihat bahwa Masyarakat Kecamatan Medan Selayang bersikap positif (kuat) atas atribut BPJS Kesehatan. Arti penilaian sub variabel sikap Masyarakat Kecamatan Medan Selayang (Abi) pada tabel 4.13 adalah sebagai berikut:

a. Sub variabel $\left(\mathrm{Ab}_{1}\right)$ nilai 0,02 berarti Masyarakat Kecamatan Medan Selayang mempunyai sikap positif (kuat) terhadap premi lebih murah dibandingkan dengan asuransi lainnya.

b. Sub variabel $\left(\mathrm{Ab}_{2}\right)$ nilai 0,01 berarti Masyarakat Kecamatan Medan Selayang mempunyai sikap positif (kuat) terhadap tersedianya pilihan jumlah premi.

c. Sub variabel $\left(\mathrm{Ab}_{3}\right)$ nilai 0,02 berarti Masyarakat Kecamatan Medan Selayang mempunyai sikap positif (kuat) terhadap jumlah premi yang otomatis tentukan kelas inap.

d. Sub variabel $\left(\mathrm{Ab}_{4}\right)$ nilai 0,24 berarti Masyarakat Kecamatan Medan Selayang mempunyai sikap positif (kuat) karena kemudahan syaratnya menjadi peserta BPJS Kesehatan.

e. Sub variabel $\left(\mathrm{Ab}_{5}\right)$ nilai 0,02 berarti Masyarakat Kecamatan Medan Selayang mempunyai sikap positif (kuat) karena manfaat perlindungan yang diberikan oleh BPJS Kesehatan.

f. Sub variabel $\left(\mathrm{Ab}_{6}\right)$ nilai 0,25 berarti Masyarakat Kecamatan Medan Selayang mempunyai sikap positif (kuat) terhadap pelayanan kesehatan diberikan oleh BPJS Kesehatan.

g. Sub variabel $\left(A b_{7}\right)$ nilai 0,01 berarti Masyarakat Kecamatan Medan Selayang mempunyai sikap positif (kuat) terhadap biaya pengobatan gratis yang ditanggung oleh Pemerintah..

h. Sub variabel $\left(\mathrm{Ab}_{8}\right)$ nilai 0,02 berarti Masyarakat Kecamatan Medan Selayang mempunyai sikap positif (kuat) terhadap tersedianya banyak Rumah Sakit sebagai Mitra dari BPJS Kesehatan.

\section{d. Norma Subjektif Keyakinan normatif dari pengaruh kelompok preferen (NBj).}

Keyakinan normatif dari pengaruh kelompok preferen (NBj) adalah gagasan yang diterima dari kelompok preferen yang berpendapat bahwa seyogyanya atau tidak seyogyanya masuk BPJS Kesehatan. Kelompok preferen adalah anggota keluarga, saudara, tetangga, teman dan iklan promosi. Nilai atribut variabel keyakinan dari kelompok preferen Masyarakat Kecamatan Medan Selayang disajikan pada tabel berikut: 
Volume 17 Nomor 2

Tabel 11: Nilai Atribut Variabel Keyakinan dari Kelompok Preferen

\begin{tabular}{|c|c|c|c|c|c|c|c|c|r|r|r|l|}
\hline $\begin{array}{l}\text { Sub } \\
\text { variabel }\end{array}$ & SS & $\mathbf{S}$ & AS & ATS & TS & STS & Jlh & & & $\begin{array}{l}\text { +/- per } \\
\text { JlhResp }\end{array}$ & R2T & \\
\hline & $\mathbf{3}$ & $\mathbf{2}$ & $\mathbf{1}$ & $\mathbf{( - 1 )}$ & $\mathbf{( - 2 )}$ & $\mathbf{( - 3 )}$ & Resp & + & - & Nilai \\
\hline $\mathrm{NB}_{1}$ & 31 & 36 & 23 & 6 & 0 & 0 & 96 & 188 & 6 & 182 & 0.25 & Kuat+ \\
\hline $\mathrm{NB}_{2}$ & 3 & 36 & 49 & 8 & 0 & 0 & 96 & 130 & 8 & 122 & 0.17 & Kuat+ \\
\hline $\mathrm{NB}_{3}$ & 4 & 34 & 50 & 8 & 0 & 0 & 96 & 130 & 8 & 122 & 0.17 & Kuat+ \\
\hline $\mathrm{NB}_{4}$ & 10 & 33 & 47 & 6 & 0 & 0 & 96 & 143 & 6 & 137 & 0.19 & Kuat+ \\
\hline $\mathrm{NB}_{5}$ & 13 & 37 & 43 & 1 & 0 & 0 & 96 & 156 & 1 & 155 & 2.22 & Kuat+ \\
\hline \multicolumn{8}{|c|}{} \\
\hline
\end{tabular}

Sumber: Diolah dari hasil kuesioner

Rata-rata skor jawaban responden dihitüng dengan cara membagi antara jumlah skor dengan jumlah sub variabel. Rata-rata tertimbang dihitung dengan cara mengalikan antara total jawaban responden untuk tiap alternatif dengan alternatif pilihan jawaban. Arti penilaian sub variabel keyakinan dari kelompok preferen (NBi) sebagai berikut:

a. Sub variabel $\left(\mathrm{NB}_{1}\right)$ nilai 0,25 berarti Masyarakat Kecamatan Medan Selayang mempunyai keyakinan yang kuat (positif) bahwa masuk BPJS Kesehatankarena pengaruh anggota keluarga.

b. Sub variabel $\left(\mathrm{NB}_{1}\right)$ nilai 0,17 berarti Masyarakat Kecamatan Medan Selayang mempunyai keyakinan yang kuat (positif) bahwa membeli BPJS Kesehatankarena pengaruh saudara.

c. Sub variabel $\left(\mathrm{NB}_{1}\right)$ nilai 0,17 berarti Masyarakat Kecamatan Medan Selayang mempunyai keyakinan yang kuat (positif) bahwa masuk BPJS Kesehatan karena pengaruh tetangga.

d. Sub variabel $\left(\mathrm{NB}_{1}\right)$ nilai 0,19 berarti Masyarakat Kecamatan Medan Selayangmempunyai keyakinan yang kuat (positif) bahwa masuk BPJS Kesehatan karena pengaruh temanteman.

e. Sub variabel $\left(\mathrm{NB}_{1}\right)$ nilai 0,22 berarti Masyarakat Kecamatan Medan Selayang mempunyai keyakinan yang kuat (positif) bahwa masuk BPJS Kesehatan karena pengaruh temanteman.

Berdasarkan tabel 4.14 di atas, nilai rata-rata atribut variabel keyakinan dari kelompok preferen Masyarakat Medan Selayang sebesar 0,2 artinya pengaruh kelompok preferen untuk membeli BPJS Kesehatansecara rata-rata memberikan pengaruh yang positif (kuat).

\section{e. Motivasi menurut preferen (MCj)}

Motivasi menurut preferen (MCj) adalah suatu variabel yang menuruti pendapat orang lain atau preferen. Variabel motivasi menurut preferen (MCj) terdiri dari: anggota keluarga, saudara, tetangga, teman dan iklan promosi. Nilai atribut variabel motivasi dari preferen pada Masyarakat Kecamatan Medan Selayang disajikan pada tabel berikut:

Tabel 12: Nilai Atribut Variabel Motivasi dari Preferen Responden

\begin{tabular}{|c|c|c|c|c|c|c|c|c|c|c|c|c|}
\hline \multirow{2}{*}{$\begin{array}{l}\text { Sub } \\
\text { variabel }\end{array}$} & SS & $S$ & AS & ATS & TS & STS & \multirow{2}{*}{$\begin{array}{l}\text { Jumlah } \\
\text { Resp. }\end{array}$} & \multirow[b]{2}{*}{+} & \multirow[b]{2}{*}{ - } & \multirow{2}{*}{$\begin{array}{l}\text { +/- per } \\
\text { JlhResp }\end{array}$} & \multirow[b]{2}{*}{ R2T } & \multirow[t]{2}{*}{ Nilai } \\
\hline & 3 & 2 & 1 & $(-1)$ & $(-2)$ & $(-3)$ & & & & & & \\
\hline $\mathrm{MC}_{1}$ & 26 & 52 & 16 & 0 & 2 & 0 & 96 & 198 & 4 & 194 & 0.28 & Kuat+ \\
\hline $\mathrm{MC}_{2}$ & 2 & 36 & 54 & 4 & 0 & 0 & 96 & 132 & 4 & 128 & 0.19 & Kuat+ \\
\hline $\mathrm{MC}_{3}$ & 2 & 29 & 51 & 8 & 4 & 2 & 96 & 115 & 22 & 93 & 0.14 & Kuat+ \\
\hline $\mathrm{MC}_{4}$ & 8 & 31 & 50 & 3 & 2 & 2 & 96 & 136 & 13 & 123 & 0.18 & Kuat+ \\
\hline $\mathrm{MC}_{5}$ & 7 & 40 & 46 & 3 & 0 & 0 & 96 & 147 & 3 & 144 & 0.21 & Kuat+ \\
\hline
\end{tabular}


Volume 17 Nomor 2

\begin{tabular}{|c|c|c|c|c|c|c|c|c|c|c|c|c|}
\hline \multirow{2}{*}{$\begin{array}{l}\text { Sub } \\
\text { variabel }\end{array}$} & SS & $S$ & AS & ATS & TS & STS & \multirow{2}{*}{$\begin{array}{l}\text { Jumlah } \\
\text { Resp. }\end{array}$} & \multirow[b]{2}{*}{+} & \multirow[b]{2}{*}{ - } & \multirow{2}{*}{$\begin{array}{l}\text { +/- per } \\
\text { JlhResp }\end{array}$} & \multirow[b]{2}{*}{ R2T } & \multirow[t]{2}{*}{ Nilai } \\
\hline & 3 & 2 & 1 & $(-1)$ & $(-2)$ & $(-3)$ & & & & & & \\
\hline & \multicolumn{7}{|c|}{ Jumlah Rata-rata Tertimbang } & 728 & 46 & 682 & 1 & \\
\hline & \multicolumn{7}{|c|}{ Rata-rata NBj } & & & & 0.2 & Kuat+ \\
\hline
\end{tabular}

Sumber: Diolah dari hasil kuesioner

Rata-rata skor jawaban responden dihitung dengan cara membagi antara jumlah skor dengan jumlah sub variabel. Rata-rata tertimbang dihitung dengan cara mengalikan antara total jawaban responden untuk tiap alternatif dengan alternatif pilihan jawaban. Arti penilaian sub variabel motivasi (MCi) sebagai berikut:

a. Sub variabel $\left(\mathrm{MC}_{1}\right)$ nilai 0,28 berarti Masyarakat Kecamatan Medan Selayang mempunyai motivasi yang kuat (positif) dari anggota keluarga untuk mmasuk BPJS Kesehatan.

b. Sub variabel $\left(\mathrm{MC}_{2}\right)$ nilai 0,19 berarti Masyarakat Kecamatan Medan Selayang mempunyai motivasi yang kuat (positif) dari saudara masuk BPJS Kesehatan.

c. Sub variabel $\left(\mathrm{MC}_{3}\right)$ nilai 1,14, berarti Masyarakat Kecamatan Medan Selayangmempunyai motivasi yang kuat (positif) dari tetangga untuk masuk BPJS Kesehatan.

d. Sub variabel $\left(\mathrm{MC}_{4}\right)$ nilai 0,18 berarti Masyarakat Kecamatan Medan Selayang mempunyai motivasi yang kuat (positif) dari teman-teman untuk masuk BPJS Kesehatan.

e. Sub variabel $\left(\mathrm{MC}_{5}\right)$ nilai 0,21 berarti Masyarakat Kecamatan Medan Selayang mempunyai motivasi yang kuat (positif) dari iklan promosi masuk BPJS Kesehatan.

Dari tabel 12 di atas, menunjukkan bahwa motivasi Masyarakat Kecamatan Medan Selayang masuk BPJS Kesehatan menuruti pendapat orang lain atau kelompok preferen secara rata-rata memberikan pengaruh yang positif (kuat).

\section{f. Norma Subjektif (SN)}

Norma subjektif (SN) merupakan norma yang berhubungan dengan gagasan orang lain menghendaki Masyarakat Kecamatan Medan Selayang membeli BPJS KesehatanNilai norma subjektif disajikan pada tabel berikut:

Tabel 13: Nilai Norma Subjektif Masyarakat Kecamatan Medan Selayang

\begin{tabular}{|c|c|c|c|c|}
\hline $\begin{array}{c}\text { Sub } \\
\text { variabel }\end{array}$ & $\begin{array}{c}\text { Keyakinan } \\
\text { Normatif (NBj) }\end{array}$ & $\begin{array}{c}\text { Motivasi } \\
\mathbf{( M C j})\end{array}$ & $\begin{array}{c}\text { Norma subjektif } \\
\mathbf{( N B j} \mathbf{x} \text { MCj) }\end{array}$ & Penilaian \\
\hline $\mathrm{SN}_{1}$ & 0.25 & 0.28 & 0.07 & Kuat/positif \\
\hline $\mathrm{SN}_{2}$ & 0.17 & 0.19 & 0.03 & Kuat/positif \\
\hline $\mathrm{SN}_{3}$ & 0.17 & 0.14 & 0.02 & Kuat/positif \\
\hline $\mathrm{SN}_{4}$ & 0.19 & 0.18 & 0.03 & Kuat/positif \\
\hline $\mathrm{SN}_{5}$ & 0.22 & 0.21 & 0.05 & Kuat/positif \\
\hline Jumlah & 1 & 1 & 0.21 & - \\
\hline Rata-rata & 0.2 & 0.2 & 0.04 & Kuat/positif \\
\hline
\end{tabular}

Dari tabel di atas, menunjukkan penilaian norma subjektif. Total nilai norma subjektif diperoleh dengan mengalikan antara keyakinan normatif (NBj) dengan variabel motivasi menurut preferen (MCj). Dari tabel di atas menunjukkan bahwa Masyarakat Kecamatan Medan Selayang berminat masuk BPJS Kesehatan karena pengaruh kelompok preferen yang secara rata-rata memberikan pengaruh yang positif (kuat). Arti penilaian sub variabel norma subjektif (SNi) sebagai berikut: 


\section{Volume 17 Nomor 2}

a. Sub variabel $\left(\mathrm{SN}_{1}\right)$ nilai 0,07 berarti Masyarakat Kecamatan Medan Selayang mempunyai keyakinan dan motivasi yang kuat (positif) dari anggota keluarga untuk masuk BPJS Kesehatan

b. Sub variabel $\left(\mathrm{SN}_{2}\right)$ nilai 0,03 berarti Masyarakat Kecamatan Medan Selayang mempunyai keyakinan dan motivasi yang kuat (positif) dari saudara untuk masuk BPJS Kesehatan

c. Sub variabel $\left(\mathrm{SN}_{3}\right)$ nilai 0,02 berarti Masyarakat Kecamatan Medan Selayang mempunyai keyakinan dan motivasi yang kuat (positif) dari tetangga untuk masuk BPJS Kesehatan

d. Sub variabel $\left(\mathrm{SN}_{4}\right)$ nilai 0,03 berarti Masyarakat Kecamatan Medan Selayang mempunyai keyakinan dan motivasi yang kuat (positif) dari teman-teman untuk masuk BPJS Kesehatan

e. Sub variabel $\left(\mathrm{SN}_{5}\right)$ nilai 0,05 berarti Masyarakat Kecamatan Medan Selayang mempunyai keyakinan dan motivasi yang kuat (positif) iklan promosi untuk masuk BPJS Kesehatan

\section{g. Niat Berperilaku}

Berdasarkan lampiran 3 diketahui total $b_{i}=1798$, total $e_{i}=1776$, total $N B j=718$, dan total $\mathrm{MCj}=682$. Dengan demikian dapat dihitung W1 dan W2 sebagai berikut:

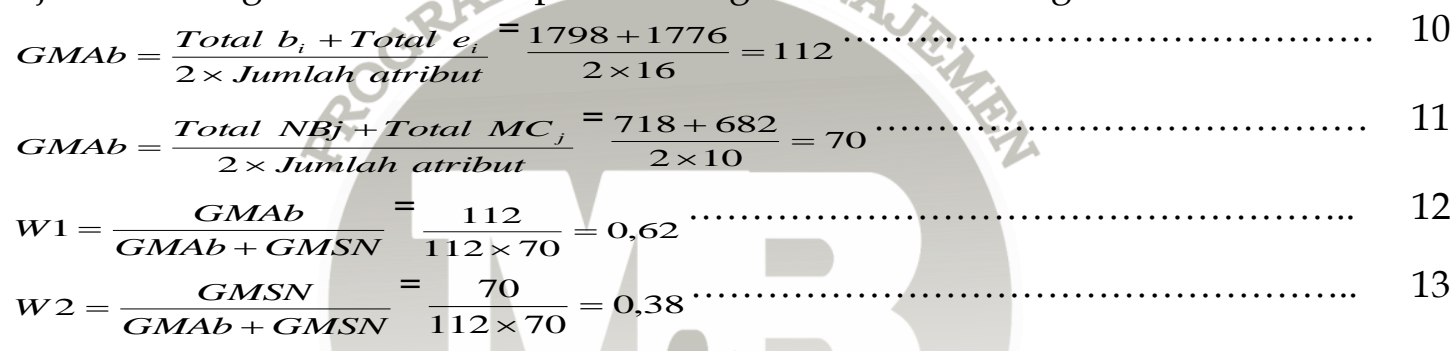

Dengan demikian diperoleh persamaan niat perilaku (BI) sebagai berikut:

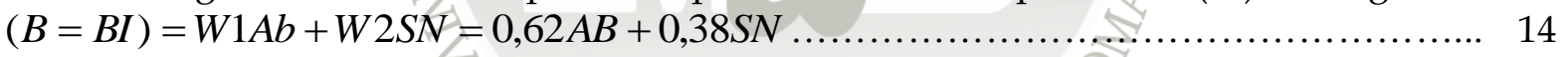

Berdasarkan persamaan di atas ternyata bahwa niat perilaku lebih besar dipengaruhi oleh sikap Masyarakat Kecamatan Medan Selayang sebesar 0,62 (62\%) dari norma subjektif 0,38 (38\%).

Suatu perusahaan hanya mampu bersaing di pasar sasaran melalui penciptaan produk/ jasa yang sesuai kebutuhan dan keinginan konsumen di pasar sasaran. Untuk mengetahui kebutuhan dan keinginan konsumen dapat dilakukan dengan melakukan survei kepuasan konsumen atas produk/ jasa yang ditawarkan ke pasar. Pada umumnya, pelanggan akan melakukan pembelian, jika produk /jasa tersebut sesuai kebutuhan dan keinginan mereka. Minat membeli dipengaruhi oleh sikap dan norma subjektif. Penelitian ini dilakukan pada Masyarakat Kecamatan Medan Selayang, jumlah sampel penelitian sebanyak 96 orang. Pembahasan variabel penelitian yang terdiri dari tiga sub variabel yakni:

1. Bahwa sikap Masyarakat Kecamatan Medan Selayang masuk menjadi peserta Mandiri BPJS Kesehatan secara rata-rata responden memberikan pengaruh yang positif (kuat) terhadap niat berperilaku.

2. Masyarakat Kecamatan Medan Selayang masuk menjadi peserta BPJS Kesehatan karena pengaruh kelompok preferen yang secara rata-rata memberikan pengaruh yang positif (kuat) terhadap niat berperilaku.

3. Berdasarkan persamaan niat perilaku $=\mathrm{BI}=0,62 \mathrm{Ab}+0,38 \mathrm{SN}$. Artinya niat perilaku lebih besar dipengaruhi oleh sikap Masyarakat Kecamatan Medan Selayang sebesar 0,62 (62\%) dari norma subjektif $0,38(38 \%)$.

\section{KESIMPULAN}

1. Sikap Masyarakat Medan Selayang masuk menjadi peserta Mandiri BPJS Kesehatan secara rata-rata responden memberikan pengaruh yang positif (kuat) terhadap niat berperilaku. 
2. Masyarakat Kecamatan Medan Selayang masuk menjadi pesewrta Mandiri BPJS Kesehatan karena pengaruh kelompok preferen yang secara rata-rata memberikan pengaruh yang positif (kuat) terhadap niat berperilaku.

3. Berdasarkan persamaan niat perilaku $=\mathrm{BI}=0,62 \mathrm{Ab}+0,38 \mathrm{SN}$. Artinya niat perilaku lebih besar dipengaruhi oleh sikap Masyarakat Kecamatan Medan Selayang sebesar 0,62 (62\%) dari norma subjektif $0,38(38 \%)$.

\section{DAFTAR PUSTAKA}

Boyd, Harper W; Walker, Orville dan Larrenche, Jean Claude, 2000. Manajemen Pemasaran: Suatu Pendekatan Strategis dengan Orientasi Global, Jilid 2, Alih Bahasa: Iman Nurmawan, Jakarta: Erlangga.

Kotler, Philip, 2000. Marketing Management, The Millenium Edition, Prentice Hall Internationsl, Inc, New Jersey.

Kotler, Philip dan Armstrong, Gary, 2001. Prinsip-prinsip Pemasaran, Jilid 1, Alih Bahasa: Damos Sihombing, Edisi Kedelapan, Jakarta : Erlangga.

Lamb, Charles W; Hair, Joseph F., McDaniel, Carl. 2001. Pemasaran. Buku 1, Alih Bahasa: David Octaveria, Jakarta: Salemba Empat.

Ndraha, Taliziduhu, 2002, Budaya Organisasi. Edisi Pertama, Cetakan Pertama, Jakarta: Rineka Cipta.

Peter, Paul J dan Olson, Jerry C. 2000. Costumer Behavior: Perilaku Konsumen dan Strategi Pemasaran. Alih Bahasa: Damos Sihombing. Jakarta: Erlangga.

Rangkuti, Freddy, 2003. Measuring Customer Satisfaction (Teknik Mengukur dan Strategi Kepuasan Pelanggan Pluas Analisis Kasus PLN-JP), Cetakan Kedua, Jakarta: PT. Gramedia Pustaka Utama.

Sugiyono, 2005. Metode Penelitian Administrasi, Cetakan Keenam, Bandung: Alfabeta.

Supranto, J., 2009. Statistik: Teori dan Aplikasi, Jilid Dua, Edisi Ketujuh, Jakarta: Erlangga.

Sutisna, 2001. Perilaku Konsumen dan Komunikasi Pemasaran, Edisi Pertama, Jakarta : Rosda.

Umar, Husein, 2001. Studi Kelayanann Bisnis: Teknik Menganalisis Kelayakan Rencana Bisnis Komprehensif, Edisi Kedua, Jakarta: Gramedia.

http:// humasrspakuwon.wordpress.com/ 2013/08/16/bpjs-kesehatan-2

http://id.wikipedia.org/wiki/Asuransi\#Asuransi_dalam_Kitab_Undang-Undang Hukum_Dagang_28KUHD

http://id.wikipedia.org/wiki/BPJS_Kesehatan

http://jkn.depkes.go.id.

http://www.bpjs.info/ketenagakerjaan/Peserta_BPIS_Kesehatan_Sumut_Peringkat

_Kedua_Nasional 